\title{
William (Wil) Vosloo - 'n Bybel-wetensakplike wat die Ou Testament vir die volk wou oopbreek
}

\author{
D J Human \\ (Universiteit van Pretoria)
}

\section{ABSTRACT}

William (Wil) Vosloo - A Biblical scholar who exposes the Old Testament for ordinary people

W Vosloo (1934-) is one of the fine Old Testament scholars in South Africa. His work on the exposition and understanding of the Bible in general, and on the Old Testament in particular, counts to the core contributions of Biblical Studies in South Africa the last two decades. This short portrait sketches Vosloo as a man of mature character and life experience. With his exposition of biblical texts, his aim was to serve the church. At university level he was a dedicated academician and lecturer. He will also be remembered as a theologian and author of. stature. William Vosloo was in his professional career really a human being for fellow humans.

\section{1 'N BELEË KRUIK VOL LEWENS ERVARING}

' $n$ Saggeaarde harde werker, iemand wie se oor en tyd altyd beskikbaar was vir studente en kollegas, ' $n$ onberispelik perfeksionis, vriendelik, netjies en deeglik, jy kan hom altyd deur ' $n$ ring trek, en moenie daardie Bolandse "bgrei"-aksent vergeet nie...so het menige studente, vriende en kollegas vir William Vosloo oor die jare leer ken.

Wil Vosloo, soos die meeste mense hom ken, is ' $n$ boorling uit die Boland. Hy is op 7 April 1934 op Franschhoek in die Kaap gebore. Daar skryf hy in 1950 aan die Hoërskool Franschhoek matriek. Hy was ook hoofseun van sy skool. In 1959 trou hy met ' $n$ bruid uit die Noord Kaap, Wilhelmina Jacoba (Winnie) Bothma. Uit die huwelik is daar drie dogters en twee seuns gebore. 'n Hele paar kleinkinders het reeds die uitgebreide Vosloo familie verryk. Vir die grootste deel van hulle lewe het die Vosloo egpaar hulle lewe in Pretoria geslyt.

Dat Wil Vosloo mense en die lewe leer ken het voordat hy predikant en teoloog geword het, is duidelik uit sy professionele loopbaan. Vir bykans twintig jaar het hy ' $n$ fyn oog ontwikkel vir mense en hulle behoeftes, geestelik en materieel. Vanaf 1951 tot 1971 het hy talle poste beklee as klerk, uitgewer, ouditklerk, rekenmeester en ook direkteur van administrasie en finansies. In 1958 verwerf hy ook die ACIS kwalifikasie (London). Hierdie ervaring sou hy later waardevol toepas toe hy as predikant en teoloog die Bybel oopbreek in gewone taal en die idioom wat sy mense sou verstaan. 
Wil Vosloo se hart was altyd in die kerk. Dit was vir die kerk se mense wat hy met sy gawes wou dien. Nadat hy sy aanvanklike teologiese opleiding voltooi het, is hy in 1971 gelegitimeer as proponent van die NG Kerk. Na die verwerwing van sy BA graad aan die Universiteit van Pretoria (1966), slaag hy sy Nagraadse Diploma in Teologie (1969), proponentseksamen (1970) en BD (1971) almal met lof. Op 16 Oktober 1982 is hy georden.

$\mathrm{Na}$ sy ordening in die NG Kerk het Vosloo die Kerk op talle terreine en in verskillende hoedanighede gedien. Hy was pastorale hulp in die NG Gemeente Hartbeesspruit. Hy dien op talle ringskommissies en was vanaf 1974 tot 1994 afgevaardigde na talle ringsvergaderings. Verder was hy afgevaardigde na sinodale vergaderings van sowel Noord Transvaal as die Algemene Sinode van die NG Kerk. Hy het bydraes gemaak op kerklike kommissies vir Bybelvertaling, die Jeug, Gemeentebou, Erediens, Interkerklike Handboek, die Psalmberymingskomitee en Geestelike Verdieping. So het die Kerk ook sy kennis en vaardighede erken en gebruik.

Wil Vosloo was ' $n$ gereelde spreker by Bybelskole en Bybelstudie geleenthede. Omdat hy die vermoë het om die Bybel eenvoudig uit te lê, is hy iemand wat verstaanbaar en eenvoudig kommunikeer. Daarom het hy vir ongeveer sewe jaar (1987-1993) aan die radioprogram "Wat se die Bybel" op die Afrikaanse radiodiens deelgeneem. So het hy saam met ander panneellede antwoorde op vrae van luisteraars rondom die $\mathrm{Ou}$ Testament beantwoord. Hy was ook ' $n$ gewilde deelnemer aan Radio Kansel programme. In verskeie gemeentes het hy gereeld as prediker opgetree.

Dit was veral sy betrokkenheid as direkteur van die Sentrum vir Voortgesette Teologiese Onderrig (1989-1998) dat Wil Vosloo gemeentelidmate en predikante se geestelike behoeftes aangespreek het. Met kort kursusse, retraits en die stigting van studiegroepe het hy SEVTO se werksaamhede by die Fakulteit Teologie aan die Universiteit van Pretoria uitgebou. Tot sy uittrede in 1998 het hy die Kerk se werk in hierdie akker bevorder en uitgebou.

\section{TOEGEWYDE AKADEMIKUS EN DOSENT}

Wil Vosloo is en was nog altyd ' $n$ toegewyde student. Dit het van hom 'n goeie akademikus en dosent gemaak.

Vanaf 1971-1979 was Vosloo dosent aan die Teologiese Fakulteit by die Universiteit van Suid-Afrika. Daarna het hy sedert 1980 tot by sy finale uittrede as dosent aan die Fakulteit Teologie by die Universiteit van Pretoria gewerk. In Oktober 1994 het hy amptelik geëmeriteer, waarna hy vanaf 1994 - 1998 tydelik-voltydse direkteur van SEVTO was. 
In 1975 slaag hy sy doktorale eksamen met Ou Testament as hoofvak (met lof). Bykomstig hiertoe het die vakke Nuwe Testament en Godsdienswetenskap sy kennis rondom die godsdienste van die NabyeOoste uitgebou. Met die titel "Die Abrahamsbeloftes in die Abrahamsvertellinge in Genesis. ' $n$ Literêre en Teologiese Analise" het hy sy DDproefskrif in 1978 verwerf.

Van ' $n$ onderwysassistent in 1971 het hy gevorder en die posisies van lektor (1971), senior lektor (1973), mede-professor (1979) en professor (1987) in die vak Ou Testament beklee. In 1987 is hy ook aangestel in die nuutgestigte Departement Bybelkunde aan die Universiteit van Pretoria waarvan hy vanaf 1989-1990 die departementshoof was.

Dit was veral vanuit sy betrokkenheid by Bybelkunde dat Wil Vosloo die belange van Bybelkunde en Godsdiensonderrig vir onderwysstudente in Suid Afrika bevorder het. Sedert 1986-1993 is hy ' $\mathrm{n}$ komiteelid van die Nasionale Departement Onderwys en Opvoeding vir Godsdiensonderrig en Bybelkunde. As verteenwoordiger van die vak het hy die saak van Bybelonderrig op skole bepleit. Uit die Suider-Afrikaanse Bybelkundevereniging (SABV), wie se stigting hy in 1981 help inisieer het, het hy hierdie werk voortgesit. Hy was van 1982-1994 voorsitter en algemene sekretaris van die Suid-Afrikaanse Bybelkundevereniging.

Vosloo was lid van 'n hele aantal akademiese en ander vakverenigings. Hy het bydraes gemaak tot die Ou Testamentiese Werksgemeenskap van Suid Afrika, die Suid Afrikaanse Vereniging vir Literatuurwetenskap asook die Suid Afrikaanse Instituut van Geoktrooieerde Sekretarisse en Administrateurs. Verder was hy lid van Bybelkor se Advieskomitee en was ook vanaf 1989-1992 lid van die Senaat van die Pretoriase Onderwyskollege.

Onder mede-studente en later sy eie studente was hy bekend vir sy deeglikheid. Sy voorlesings was deeglik voorberei. Daarom was hy ook in talle opsigte ' $n$ goeie administrateur. Beplanning was een van die sleutels tot sy akademiese sukses. Afgesien van sy voorgraadse lesings het hy ook nagraadse studente begelei. Hy was betrokke by die eksaminering van 11 doktorale eksamens, terwyl vier kandidate hulle proefskrifte onder sy promotorskap voltooi het.

\section{TEOLOOG EN SKRYWER}

As Bybelwetenskaplike het Wil Vosloo die binnekamer van die Bybel vir sy hoorders en lesers oopgemaak. Dit was veral as skrywer en redakteur dat hierdie teoloog hom aan sy taak toegewy het.

In Suid-Afrika het hy reeds met sy proefskrif ' $n$ belangrike bydrae tot die $\mathrm{Ou}$ Testamentiese wetenskap begin maak. In ' $\mathrm{n}$ tyd toe die immanente lees van die Ou Testament belangrik was, het hy positief teenoor die historiese kritiek gereageer. Tog het hy die belang van die Bybelse 
teks in sy finale vorm beklemtoon (Le Roux 1993:197) ${ }^{1}$. Sy bydrae tot "gebalanseerde strukture" en die narratologiese lees van Ou Testamentiese tekste kan nie onderskat word nie. Verder was dit hy wat erken het dat ' $n$ teks nie net een betekenis het nie, maar dat daar verskeie "betekenisse" in die lees van " $n$ Bybelse teks moontlik is (Le Roux, 1993:200).

Vanaf die vroeë tagtiger jare het hy gereeld met bekende Bybelwetenskaplikes in Suid Afrika as redakteur saamgewerk om baanbreker publikasies daar te stel. Ferdinand Deist, Izak du Plessis, Riempies Prinsloo en Fika van Rensburg het saam met hom as redakteurs opgetree.

Binne die Suid-Afrikaanse en Afrikaanse gemeenskap sal Vosloo veral onthou word vir sy mede-aandeel aan die totstandkoming van die Bybel in Praktyk (1993) en Die Bybellenium Eenvolume kommentaar (1999). Saam met Fika van Rensburg het hy as Ou Testament redakteur hierdie pionierswerk in Afrikaans help daarstel. Die Bybellenium is 2000 ook met die Andrew Murrayprys in bekroon. Met hierdie projekte het hy ' $n$ enorme bydrae tot die gewone lidmaat se lees en verstaan van die Bybel gemaak. Vir hom was dit belangrik dat mense die taal en tydsgees in die verklaring van Bybelboeke moet hoor. So bly ou Bybeltekste steeds lewendig vir die sogenaamde "post-moderne" mens van vandag.

\section{5 'N MENS VIR MENSE}

Benewens al sy talle bekwaamhede staan die persoonlikheid van Wil Vosloo in die teken van menslikheid en welwillendheid. Hy is ' $n$ mens vir mense. Die Bybeltekste wat hy talle male deurgeworstel het, het merktekens op sy lewe gemaak. Hierdie kenmerke het ook afgevryf op almal wat met hom in aanraking gekom het. Dit was en is steeds aangenaam om met hom saam te werk en sy vriendskap te geniet.

Hierdie feesbundel is ' $n$ poging om aan William Vosloo dankie te sê vir sy bydrae tot die verstaan van die Bybel en die Ou Testamentiese wetenskap. By hom kon studente, kollegas en gewone lidmate leer om die Bybel beter te begryp. Ons wens hom saam met sy familie alles van die beste vir die toekoms. Mag sy pen en vaardighede nog lank besig wees met die $\mathrm{Ou}$ Testament en die Bybel.

\footnotetext{
${ }^{1}$ Le Roux J H 1993. A story of two ways. Thirty years of Old Testament scholarship in South Africa. Pretoria: Verba Vitae.
} 
Ten einde ' $n$ meer volledige beeld op William Vosloo se akademiese bydrae te werp, bevestig die volgende lys van publikasies sy pennevrug:

\section{Boeke: Akademies}

- "Die Voorgeskiedenis" en "Die Aartsvaders", in Van Zyl, A H (red), Israel en sy bure. Durban: Butterworths, 1977. pp 2-71.

- "The Prehistory" en "The Patriarchs", in Van Zyl, A H (ed), Israel and her neighbours. Durban: Butterworths, 1979. pp 2-71.

- Deist, F, W Vosloo \& I J du Plessis (reds), Van Eden tot Rome. Pretoria: J L van Schaik, 1981, $58 \mathrm{pp}$.

- Deist, F, W Vosloo \& I J du Plessis (eds), From Eden to Rome. Pretoria: J L van Schaik, 1982, 63 pp.)

- "Die Nuwe Afrikaanse Bybelvertaling: 'n Beoordeling van die Ou Testament", in Wethmar, C J (red) Die taal van die Bybel en die predikant. UPTS 1. Pretoria: NG Kerkboekhandel, 1986, pp 12-30.

- Méér as net 'n storie. Pretoria: NG Kerkboekhandel, 1986, 270 pp.

- Great tales... Greater truths. Pretoria: SACUM, 1987, 284 pp.

- "Die verhouding tussen Ou Testament Teologie en Inleiding", in Prinsloo, W S \& W Vosloo (reds), Die Ou Testament Teologie: Gister, vandag en môre. UPTS 4. Pretoria: NG Kerkboekhandel, 1987, pp 79-98.

- "Die tuinverhaal. 'n Narratologiese ondersoek van Genesis 2-3", in Prinsloo, W S \& W Vosloo (reds), In mensetaal oor God se Woord. Huldigingsbundel opgedra aan professor A H van Zyl. Kaapstad: Lux Verbi, 1988, pp 158-174.

- "Hosea", in Van Zyl, A H, (red), Verklarende Bybel. Kaapstad: Lux Verbi, 1989, pp 975-986.

- "Die profete" en "Huweliksdiens", in Barnard, A C, (red), Die jaar van God se genade. Pretoria: NG Kerkboekhandel, 1989, pp 94-98 \& 156-160.

- "Genesis", "1 \& 2 Samuel", "1 \& 2 Konings", "Hosea", "Die tussentestamentêre tyd", "Die gebruik van die Ou Testament in die Nuwe Testament", in Vosloo, W \& F van Rensburg (reds), Die Bybel in Praktyk. Vereeniging: CUM, 1993, $356 \mathrm{pp}$.

- "Die tweekantigheid van menswaardigheid (Genesis 2-3)", in Vos, C J A \& J C Müller (reds), God, Mens en Wêreld IV: Menswaardig. Pretoria: Orion, 1994, pp 68-77.

- "Genesis" in Verwysingsbybel 1983-vertaling, Band I. Kaapstad: Die Bybelgenootskap van Suid-Afrika, 1998, pp 1-64.

- "Genesis", "Hosea" en bylaes in Die Bybellennium Eenvolumekommentaar. Vereeniging: CUM, 1999, pp $151 \mathrm{pp}$.

\section{Tydskrifartikels: Akademies}

- Op soek na die oorsprong van die begrip "die Dag van die Here". Theologia Evangelica, 8/3 (1975), 183-189.

- Die vrou van Hosea - 'n Ontugtige?, Ned Geref Teol Tydskrif, 17/3 (1976), 159174.

- Die invloed van sy omgewing op die beeldspraak van Amos, Theologia Evangelica, 10/2 \& 3 (1977), 7-10.

- Balance structures in the Old Testament: A brief survey, Theologia Evangelica, 12/1 (1979), 48-60. 
- Salôm - Die Ou-Testamentiese "vredesbeskouing" en die Christen, Skrif en Kerk, $1 / 1$ (1980), 57-69.

- Die historiese betroubaarheid van die aartsvadervertellinge. 'n Beknopte bespreking van die huidige debat na aanleiding van die jongste publikasie, Skrif en Kerk, 1/3 (1982), 44-57.

- Rûah/gees in die Ou Testament, Skrif en Kerk, 4/2 (1983), 40-68.

- Faktore verantwoordelik vir die insinking en oplewing in die geestelike lewe van ou-Israel, Skrif en Kerk, 6/1 (1985), 90-101.

- Die troue God is my Beskermer - Psalm 59, Skrif en Kerk, 8/2 (1987), 223-234.

- Belewenisse en behoeftes van predikante. 'n Steekproef vir verdere ondersoeke (saam met J H Bisschoff), NGTT, 4/30 (1989), 563-573.

- Bybelkunde: Is die studieveld vanselfsprekend?, Scriptura, 34 (1990), 38-47.

- Valse verwagtinge aan die kaak gestel: Die funksie van die heilstradisies in Jeremia 7:1-15 (saam met M D Terblanche), Skrif en Kerk, 2/11 (1990), 221-229.

- "Uit Egipte geroep" - 'n Kontekstuele benadering van Hosea 11, NGTT, 31/4 (1990), 500-508.

- Die koning op 'n donkie, of 'n donkie vir die Koning? Sagaria 9:9-10, NGTT, 32/3 (1991), 353-359.

- Die samestelling en struktuur van die boek Hosea. Skrif en Kerk 13/2 (1992), 244-252.

- Fokus op armoede. NGTT 35/1 (1994), 55-64.

- One small step for Biblical Studies... The growth of the SA Biblical Studies Society, Scriptura, 54 (1995), 177-187.

- "Willem Sterrenberg Prinsloo gesien deur die oë van 'n kollega", Skrif en Kerk 19/3 (1998), 485-490.

\section{Populêre publikasies: Boeke en tydskrifte}

- Probleme rondom die teologiese studies, Die Kerkbode, 30 September 1970, 481.

- Kerk moet vir sy studente sorg, Die Voorligter, 34 (Sept 1971) 4-9.

- Administrasie of konsternasie, Deo Gloria, 41 (1980) 7-9.

- Waar staan ons met Bybelkunde? Ons Jeug, 33 (Sept 1984) 202.

- Waar staan ons met Bybelkunde? (verv), Ons Jeug, 33 (Okt 1984) 224.

- Lewe: Ou Testament, Ons Jeug, 39 (Jan 1990) 2 \& 23.

- Die Departement Bybelkunde en Die Sentrum vir Voortgesette Teologiese Opleiding, Deo Gloria, (1990) 18.

- Vosloo, W, F van Rensburg \& G Veldhuizen Wat die Bybel sê. Deel I. Pretoria: J P van der Walt, 1991, 209 pp.

- Die Ou Testament oor demone en die Satan. In die Skriflig 26/3 (1992) 387-396.

- "My seun, jy moet luister..." Gesag in die Ou Testament. Deo Gloria (1993) 12 14.

- Die rol van SEVTO in 'n nuwe Suid-Afrika. Deo Gloria (1994) 13.

- SEVTO se voortgesette funksie. Deo Gloria (1995) 22.

- Voortgesette opleiding en spiritualiteit. Deo Gloria (1996) 6.

- "Leef jou geloof?" in Maak dit jou beste jaar ooit! Vanderbijlpark: Carpe Diem Boeke, 1997, 49-53.

- Die stukkend wat ons ontken. Deo Gloria (1997).

- In die begin. 'n Bybelstudie oor Genesis 1-11. Vereeniging: CUM, 1998, 100 pp.

- "Geloof" in Die oorvloed wat God gee. Vanderbijlpark: Carpe Diem Boeke, 1998, 96-102. 
- "Vergifnis verander alles" in Die nuwe Maak dit jou beste jaar ooit! Vanderbijlpark: Carpe Diem Boeke, 1998, 41-45.

- "Maak jou geloof sigbaar" in Maak 2000 jou beste jaar ooit! Vanderbijlpark: Carpe Diem Boeke, 1999, 46-47.

- "Vyf vrae oor geloof" in Man se lysies vir die lewe. Vanderbijlpark: Carpe Diem Boeke, 2000, 79.

- "Lééf in geloof" in Vrou se lysies vir die lewe. Vanderbijlpark: Carpe Diem Boeke, 2000, 107.

- "Geloof is om soms te twyfel" in Loflied aan die lewe. Vanderbijlpark: Carpe Diem Boeke, 2000, 36-37. 